\title{
THE USING OF MODERN MARKETING TOOLS IN THE CONTEXT OF SOCIAL RESPONSIBILITY OF BUSINESS
}

\author{
Tetiana Kulinich ${ }^{1}$, Nataliia Terentieva ${ }^{2}$
}

\begin{abstract}
The article is devoted to the problem of using modern marketing tools in the context of corporate social responsibility. It was offered the mechanism of introduction of principles of social responsibility of business through implementation of the concept of socio-ethical marketing in business practice. It was substantiated the elements of the marketing complex for the concept of socio-ethical marketing and the modern vision of this concept, which involves the use of digital marketing tools to promote goods, services and ideas. It was analyzed the factors of global influence on the conditions of doing business, which were formulated in the following areas: a single information space; creation of new business models using artificial intelligence; the economy of shared consumption, which enhances the ability to access various sources of information, providing a multidimensional picture of consumer behaviour; increase consumer loyalty to the use of digital search tools about the characteristics of the product and the possibilities of its purchase and further use; new systems of marketing information in terms of expanding its subsystem of Internet research; the spread of cognitive technologies creates new approaches to information processing and management principles, and also contributes to the transformation of many areas of social and economic development in terms of displacing human labour as a factor in the production of some of them. It was proposad the author's approach to the modern interpretation of socio-ethical marketing, which is based on the needs of consumers in the context of the principles of social responsibility and modern digital tools for their implementation, taking into account the factors of global influence. In the context of such an approach, ethical norms and principles of corporate social responsibility must be implemented. The main purpose of socio-ethical marketing should be the formation of consumer loyalty through the creation of associations with social programs conducted by enterprises and organizations. In this context, the tasks of socio-ethical marketing should be: the analysis of the target audience; development of measures to form a system of customer loyalty and strengthen the position of the brand in a niche market; the improving the quality of goods and services and their compliance with socio-economic and environmental standards; the formation of a system of measures that will improve the quality of life. It was carried out the analysis of marketing tools in the context of realization of the concept of socioethical marketing in the conditions of digitalization. It was considered the conditions of development of digital marketing tools. It was determined that the marketing tools that are implemented in the digital economy have certain advantages in the formation of socially defined attributes and needs of specific social groups. However, it does not sufficiently regulate the ethical issues of using personal data of consumers in the context of digitalization. However, studies show a trend of change in the field of socio-ethical relations with consumers, the formation of a paradigm of social responsibility of doing business in new conditions with the spread of cognitive technologies for managing consumer behavior.
\end{abstract}

Key words: consumer marketing, social responsibility, marketing tools, the concept of socio-ethical marketing.

JEL Classification: M31, L86, A13, Z32

\section{Introduction}

In the era of rapid innovative business development (Aaker, 2003), social responsibility is the obligation

\footnotetext{
Corresponding author:

${ }^{1}$ Lviv Polytechnic National University, Ukraine.

E-mail: tetiana.v.kulinich@lpnu.ua

ORCID: https://orcid.org/0000-0003-0110-7080

ResearcherID: R-6627-2017

${ }^{2}$ Zaporizhzhya National University, Ukraine.

E-mail: terentieva_nataliya@ukr.net

ORCID: https://orcid.org/0000-0001-6930-879X
}

of business to make a voluntary contribution to the development of society, including all areas - economic, social, environmental, innovative and other areas. 
In today's global world, socio-ethical issues of doing business are becoming increasingly important (Barna, Melnyk, Baran, 2021). Among the key modern trends of dynamic revolutions are the informatization of society, digital economy, social integration, globalization of markets and more. The outlined trends reinforce the temporal factor of change and require a rapid response to them not only in the conceptual sense, but also in applied aspects. Current trends and various challenges undoubtedly influence the formation of new marketing tools, directing them to the social context, as social responsibility and marketing ethics are a projection of these trends and changes, should be based on high socio-humanistic standards. With this in mind, domestic businesses should be aware of and use the benefits of socioethical marketing as a long-term perspective, exclusive competitive advantage, special reputational capital.

In European countries, the concept of social responsibility was officially formed at the end of the XX century and was reflected in the document of the European Commission "Green Paper" (2001). According to the Green Paper of the European Union (2001), corporate social responsibility means the integration of social and environmental aspects into the day-to-day commercial activities of enterprises and their interaction with stakeholders on a voluntary basis (Barna, Melnyk, Baran, 2021). Given this approach to the implementation of the principles of social responsibility in all spheres of society, the implementation of these measures is carried out at different levels and contributes to the implementation of sustainable development strategies in the international community, the country and businesses. Based on this vision, the concept of social responsibility is justified for use at different socio-economic levels: international or global, national, regional, local (community) and at the level of business units.

Ukraine has committed itself to implementing the principles of sustainable development at all socio-economic levels, which has contributed to the promotion of the concept of social responsibility as a practical mechanism for implementing these principles. A significant contribution to the introduction of the principles of sustainable development and the development of the concept of social responsibility belongs to the business sector. The idea of public service has long historical roots in the business sphere and is realized through the mechanisms of voluntary contributions of business to the development of society in social, economic and environmental spheres related to the main activities of the company or beyond a certain minimum (Chukurna, 2020). This approach is aimed at introducing the principles of sustainable development through the concept of social responsibility.

\section{Methodology of research}

\subsection{Theoretical aspects of the formation of the concept of socio-ethical marketing}

The practical implementation of the concept of social responsibility is possible through modern tools of socio-ethical marketing, which aims to meet the needs not only of a particular group of consumers, but also the needs of society as a whole. This mechanism ensures the practical use of corporate social responsibility in the context of the main directions of sustainable development, namely: social, economic and environmental.

The methodological basis of the study is based on the research of many scientists who have substantiated various aspects of the development of the concept of socio-ethical marketing. The problem of social responsibility of the company is considered in the works of such scientists as S. Aaronson, S. Adame, R. Bennett, T. Bradgard, D. Woody, P. Drucker, A. Carroll, A. McWilliams, P. Rodriguez, R. Solomon, P. Watchman, M. Forster, M. Friedman, K. Fukukawa, S. Hedberg, A. Shapiro.

Theoretical foundations of the evolution of marketing concepts have been studied by many scientists, namely: Aker D. (2003); Drucker P. (2004), Kotler F. (2012), Keller K. (2005), Minzberg G., Lamben J.-J. (2004), Porter M. (2005), Martyniuk O.A. (2020), Oklander M. (2020), Chukurna O. (2020), etc. Despite the significant contribution of scientists to the development of the theory and evolution of marketing concepts, the further implementation of approaches to sustainable development strategies have created the conditions for updating the principles of social responsibility in business practice. The study of the implementation of these principles is in the process of constant transformations and changes, which is associated with many factors that affect the socio-economic processes in society. This determined the need to study modern marketing tools, the use of which will contribute to the implementation of the principles of social responsibility.

\subsection{Theoretical principles of transformation of modern marketing tools in the concept of socio-ethical marketing as a mechanism for implementing social responsibility of business}

The concept of socio-ethical marketing arose as a result of the search for measures to rationalize consumption, humanize production and environmental protection of society from unwanted processes of production and consumption.

The founder of the classical theory of marketing F. Kotler substantiated the concept of socio-ethical 
marketing, the mandatory conditions for the implementation of which are the following:

- the main purpose of the enterprise should consist in meeting the various needs of customers in accordance with the interests of society;

- the need for constant search and development of goods that better meet the demand that meets the interests of consumers;

- the availability of constant work to increase the loyalty of regular and potential consumers.

In the traditional sense, socio-ethical marketing involves minimizing the negative consequences for society through irrational consumption, taking into account ethical norms and environmental principles. The modern view of the concept of socio-ethical marketing should be based on the use of the latest and innovative tools for promotion, digitalization, the emergence of new standards of consumption and the achievements of cognitive technologies. In addition, the using of modern marketing tools in the digital economy exacerbates the problems of ethics and the use of personal data of consumers. The problem of using modern marketing tools in accordance with the concept of social responsibility is exacerbated by global factors influencing the conditions of doing business, which can be represented in the following areas:

1) In the context of globalization, when the information space becomes unified, consumer behaviour changes towards loyalty to the use of digital search tools about the characteristics of the product and the possibilities of its acquisition and subsequent use. In this context, it were widely used a following instruments: SMM tools, marketplaces (Rozetka, Prom.ua), platforms for comparing the price characteristics of goods (Price.ua). Thus, consumers become researchers who react instantly to any changes in the characteristics of the product.

2) There are created new operational business models on the basis of the latest digital platforms, which allow to collecting and processing analytical data on consumer's behaviour. This allows you to use targeting when promoting goods and services over the Internet and simplifies the collection of marketing information.

3) There are formed a new systems of marketing information in terms of expanding its subsystem of Internet research, which can be organized on a regular basis.

4) Under the influence of global factors formed a fundamentally new type of economic relations - the economy of shared consumption, which enhances the ability to access various sources of information, from personal to industrial, providing a multidimensional picture of consumer behaviour. The phenomenon of the economy of shared consumption is the technological opportunity for individuals or legal entities to share a product or service at a level that was previously impossible. Such distribution of goods or services becomes possible with the help of virtual platforms and mobile platforms. They contribute to the reduction of transaction costs in the system to such an extent that all its participants receive economic benefits.

5) The economy of shared consumption contains a number of components and characteristics or descriptions: technological component, the advantage of access over ownership; interaction between two equal parties; shared access to personal assets; ease of access; strengthening social interaction; consumption in cooperation and feedback from consumers in free access (Chukurna, 2020).

6) The spread of cognitive technologies and artificial intelligence creates a new system not only information processing and new management principles, but also contributes to the transformation of many areas of social and economic development by displacing people from areas such as: services; trade; office and administrative activities; maintenance and repair; production; transportation and logistics; management; marketing; business.

Given the above provisions, the author's approach to the modern interpretation of socio-ethical marketing is based on the needs of consumers in the context of the principles of social responsibility and modern digital tools for their implementation, taking into account factors of global influence.

In contrast to the traditional understanding of the concept of socio-ethical marketing, which aims to meet the needs of consumers in the interests of society, the modern vision of this concept involves the use of digital tools to promote goods, services and ideas. It must be implemented an ethical norms and principles of corporate social responsibility in the context of such an approach. As moral and ethical norms of use of personal data of consumers are an actual question of modern development of the theory and practice of marketing. In addition, the traditional concept of marketing aims at a constant violation of needs and demand, and this leads not only to meet the needs and desires of customers, but also to the desire for unbridled profit growth, which, as practice shows, often causes violations of rational consumption, lack raw materials, energy resources, environmental pollution. In this context, the using of the principles of social responsibility through the tools of socio-ethical marketing are aimed at solving these problems. At the same time, the main purpose of socio-ethical marketing is to form consumer loyalty by creating associations with social programs conducted by enterprises and organizations. In this context, the tasks of socio-ethical marketing should be: analysis of the target audience; development of measures to form a system of customer loyalty and strengthen the position of the brand in a market niche; improving the 
quality of goods and services and their compliance with socio-economic and environmental standards; formation of a system of measures that will improve the quality of life.

The using and implementation of the conceptual foundations of socio-ethical marketing will promote the development of social responsibility of society. However, in the context of digitalization and informatization of society, the tools of socio-ethical marketing are changing, using innovative technologies that analyze the demands of the target audience, make a portrait of the consumer, respond quickly to changing consumer priorities and increase demand and customer loyalty.

All these trends, which intensify the formation of the economy of shared consumption and the use of cognitive technologies in marketing contribute to the transformation of the marketing complex in terms of the social component of each element of the marketing complex, emphasizing corporate social responsibility and adding another element of the marketing complex the consumer.

Thus, the concept of socio-ethical marketing, implementing the principles of corporate social responsibility, creates the basis for further development of long-term partnerships with the consumer, who joins the promotion process and becomes an active participant. This approach becomes possible and is actively developing due to the use of digital marketing tools that promote the active involvement of the consumer in the system of marketing activities of the manufacturer of goods and services (Martyniuk, 2020).

\section{Results and discussion}

\subsection{Development of the market of digital marketing tools}

The use of digital channels to promote and move businesses online has been growing rapidly in recent times. According to Soul Partners, Baker Tilly Ukraine and Aequo, with the support of the USAID Competitive Economy of Ukraine program, a study of the e-commerce market in Ukraine for 2020 was conducted. According to the results of the study, since the beginning of the coronavirus pandemic, the market size has grown by $41 \%$. The growth of retail trade in the e-commerce market has increased in recent years by almost 3 times (Figure 1). This is almost twice as high as the average in Central and Eastern Europe $21.5 \%$ (eMarketer).

The main drivers of growth of the e-commerce market in Ukraine are the following: increasing the level of Internet coverage and the number of smartphone users; quarantine restrictions associated with the coronavirus pandemic; growing confidence in digital payment systems. In the top of the largest marketplaces in Ukraine: Rozetka, Prom, Allo, Bigl and Epicentr (Figure 2).

Ukraine has the lowest annual level of spending per person in e-commerce compared to neighbouring countries - \$104. The most spent in the Czech Republic - \$ 841 (Figure 3).

Another modern marketing tool that has developed in the digital economy is Social Shopping. This tool is actively developing in the world and it is expected that it will gain popularity in Ukraine as well. Today, the development of Social Shopping in Ukraine is limited to the use of the "old school" method or through direct communication. However, global trends in this direction are due to the fact that in Ukraine later appear the functions of shops and shop windows in social networks. The main marketplace of Social Shopping in Ukraine remains Instagram, especially for small local brands (Figure 4).

According to research on sales of Social Shopping tools, $12 \%$ of women and $2.8 \%$ of men buy clothes, shoes, accessories through the social network Instagram.

The spread of social networks as a marketing tool for promotion and sales contributes to several important trends in the field operation of online stores.

Firstly, consumers switch to using video content when making a choice and, even on the pages of the site, want to view products in dynamics. That is why it is increasingly important to fill the site with video content, which helps to improve consumer perception and increase loyalty.

Secondly, users on social networks use information gained from the experience of interacting with leaders who shape public opinion and bloggers who broadcast personal experiences of using the product. The presence of photo and video content with real consumers of goods, in the presence of reviews, enhances the perception of the product and promotes loyalty.

Another most effective modern marketing tool to influence consumer behavior, the formation of loyalty systems and the promotion of goods and services are mobile applications. Today, almost all large companies, banks, retail have their own mobile applications that allow not only to form a system for promoting services, but also to form a system for collecting and analyzing marketing information.

In addition, mobile applications are a way to attract an active audience of consumers who have a high degree of mobility and engagement in an interactive digital space. In addition, mobile applications have a high level of customer focus, which is why they are used by consumers who value their time.

The main barriers to online sales are the danger of unethical use of personal data of consumers, the inability to verify the quality of the product and the difficulty of trusting online stores (Figure 5). 
Vol. 2 No. 3, 2021

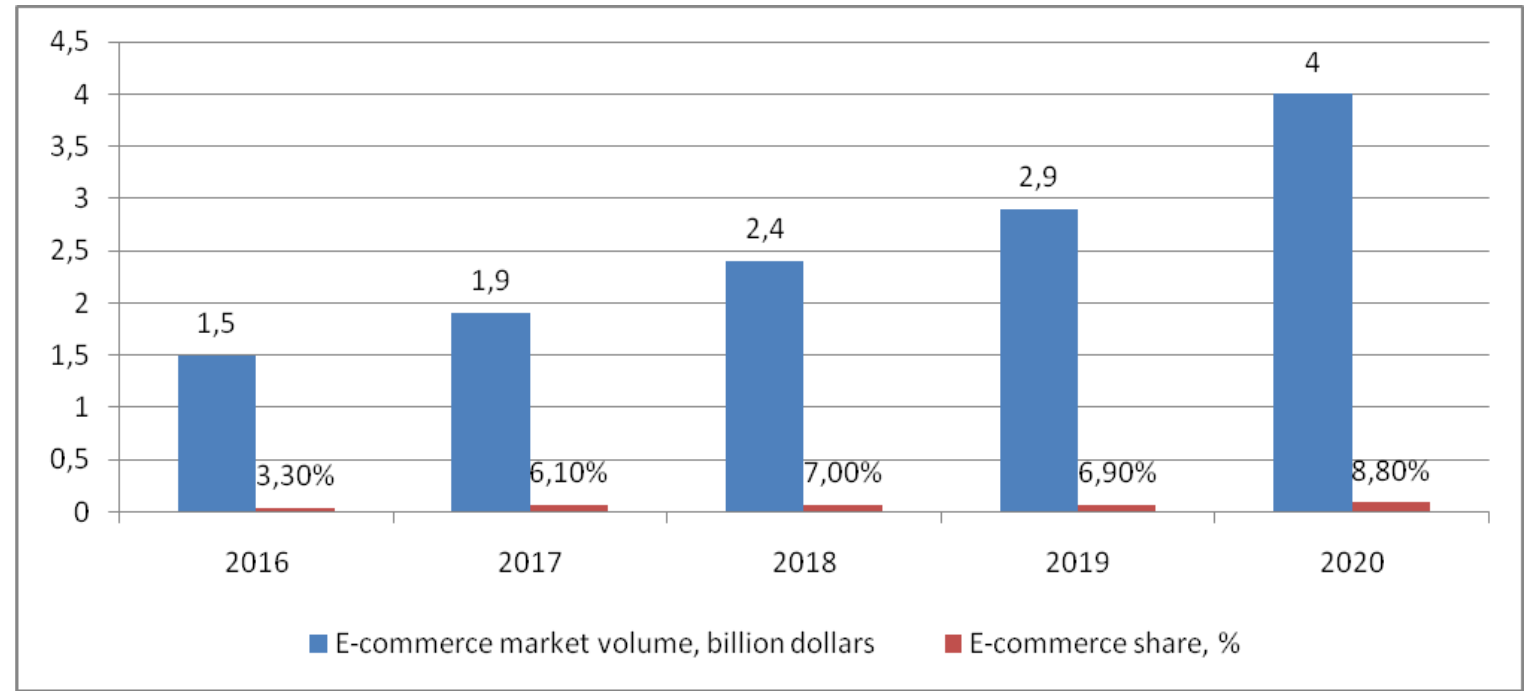

Figure 1. The volume of the e-commerce market, billion dollars

Source: Compare the Market, 2021

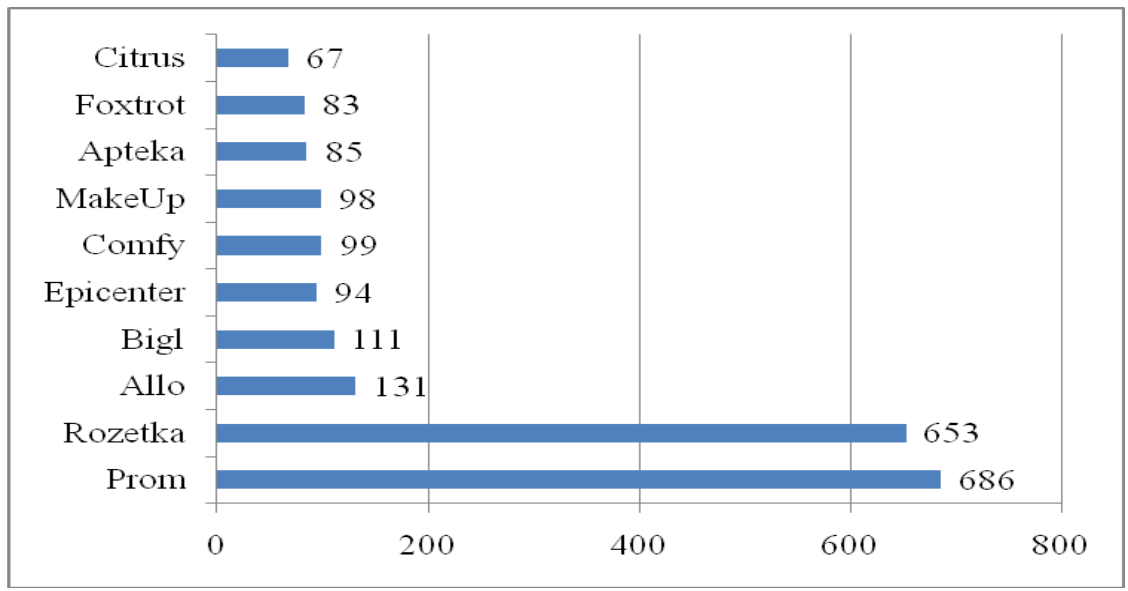

Figure 2. The largest marketplaces in Ukraine, billion dollars

Source: Compare the Market, 2021

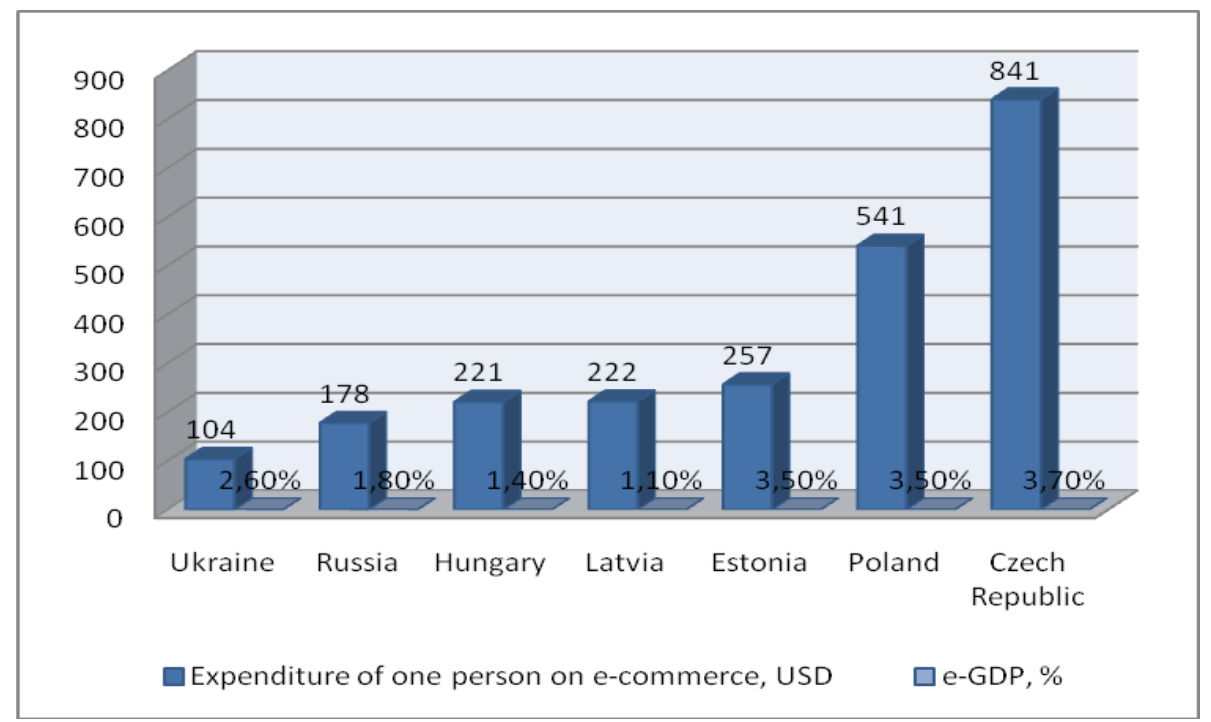

Figure 3. The amount of spending per person on e-commerce per year (USD) compared to the e-GDP of the country $(\%)$

Source: Data Bridge, 2021 


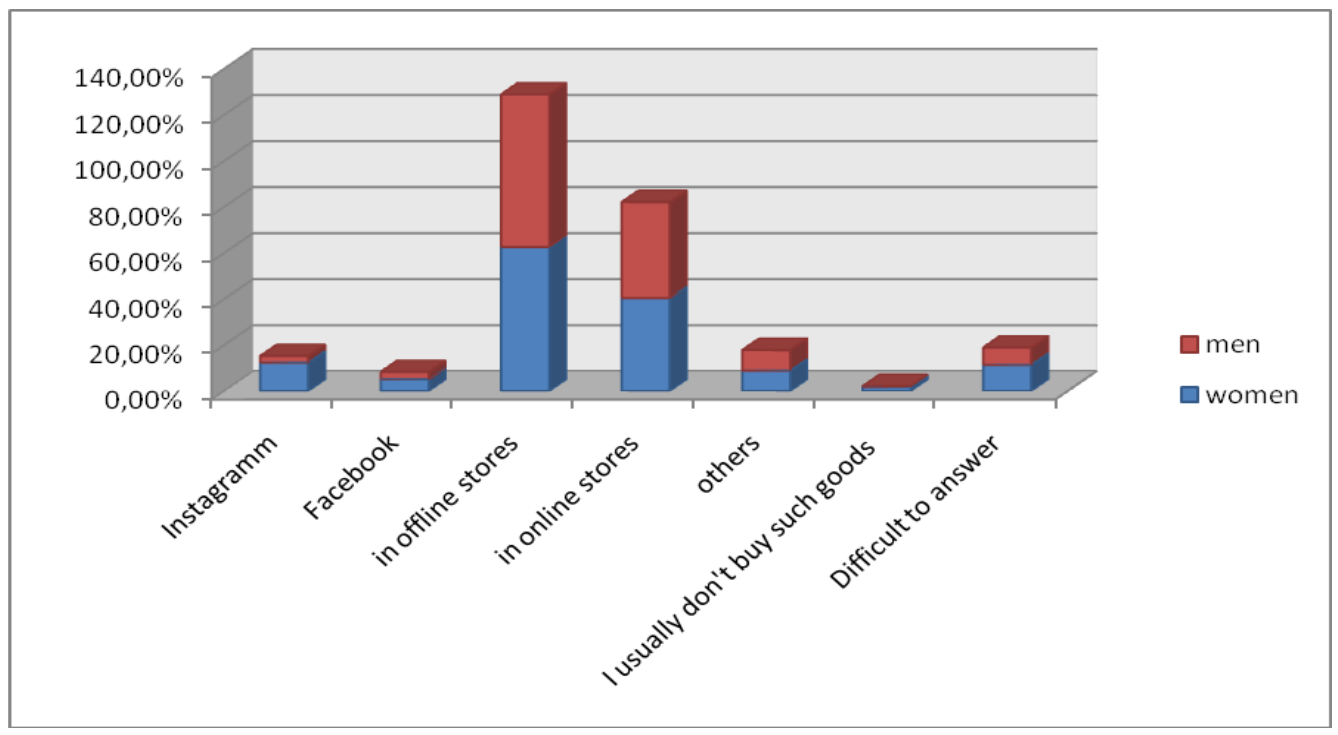

Figure 4. Dynamics of Social Shopping development in Ukraine

Source: (Chukurna, 2020)

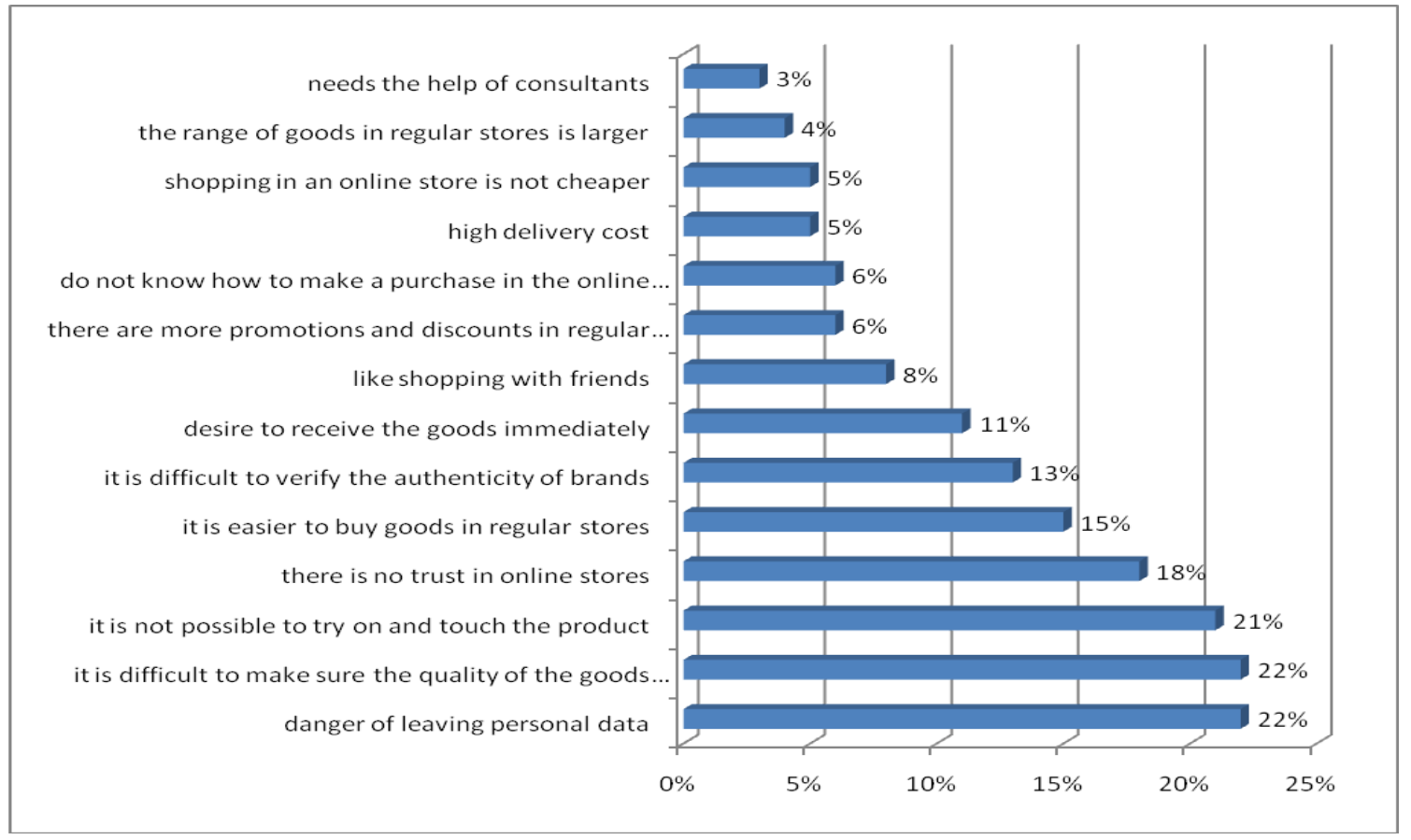

Figure 5. Online barriers for users of online stores and E-commerce

Source: Data Bridge, 2021

In order to reduce these barriers, E-commerce and online stores are developing secure agreements with sellers on marketplaces and creating opportunities for live interaction with the product.

In addition, there is a tendency to create points of delivery of goods in online stores. For example, large marketplaces, such as "Rozetka" are actively offline, not only opening their stores, but also selling the franchise. In turn, Kasta opened 50 branches in Ukrposhta's premises to provide fitting. "Nova Poshta" has accelerated the development of the network of post offices to get even closer to the home of buyers and increase the value of delivery (no need to stand in line, contact people, you can pick up the parcel 24/7).

The most of these measures are aimed, inter alia, at reducing the delivery price, which averages $5 \%$ to $15 \%$ of the purchase price. As the number of orders increases, buyers will increasingly pay attention to the availability of free delivery in the online store and the possibility of free return. 


\subsection{Identification of marketing tools that can provide the principles of CSR}

Digitization and spread of e-commerce have contributed to the formation of new marketing tools for promotion and sales. Let's analyze modern marketing tools that ensure compliance with the principles of social responsibility and at the same time provide for the use of digital promotion channels (Table 1).

Given the above comparative analysis of marketing tools that ensure compliance with the principles of social responsibility and provide for the use of digital promotion channels, it can be concluded that the issues of ethical use of personal data of consumers are insufficiently regulated. The above marketing tools, which are implemented in the digital economy, have certain advantages in the formation of socially defined attributes and needs of specific social groups. However, it does not sufficiently regulate the ethical issues of using personal data of consumers in the context of digitalization. However, research shows a trend of change in the field of socio-ethical relations with consumers, the formation of a paradigm of social responsibility of doing business in new conditions with the spread of cognitive technologies for managing consumer behaviour. All these trends contribute to the actualization of the formation of socially

Table 1

Modern marketing tools that ensure compliance with the principles of social responsibility and provide for the use of digital promotion channels

\begin{tabular}{|c|c|c|}
\hline $\begin{array}{c}\text { Modern marketing } \\
\text { tools }\end{array}$ & Advantages & Disadvantages \\
\hline \multicolumn{3}{|c|}{ 1) Digital marketing tools } \\
\hline SEO & $\begin{array}{l}\text { Long-term result and the ability to promote the site yourself. } \\
\text { Increase site traffic. Not very significant costs for promotion. High } \\
\text { conversion of site visitors into buyers. Minimum of the negative } \\
\text { effect of imposing on the buyer. Simplify target audience search. }\end{array}$ & $\begin{array}{l}\text { A time consuming tool that requires constant } \\
\text { support efforts. The first results become apparent } \\
\text { only after several months of site operation. } \\
\text { Requires constant monitoring of site content to } \\
\text { meet search engine queries. Timely updating of } \\
\text { site content. The need to adapt the same site to } \\
\text { the criteria of different search engines. }\end{array}$ \\
\hline SMM & $\begin{array}{l}\text { Availability of an interactive audience. Absence or low level of } \\
\text { advertising costs on social networks. Ability to quickly work with } \\
\text { suggestions and objections from customers. Forming an audience } \\
\text { of regular customers who will monitor the development of the } \\
\text { company, changes, promotions, etc. }\end{array}$ & $\begin{array}{l}\text { Not suitable for B2B market. Not all areas are } \\
\text { progressing equally well on social networks. SMM } \\
\text { usually works well for markets B2C and C2C. The } \\
\text { need to spend a lot of time on the community. } \\
\text { Social networks need constant attention. A long } \\
\text { break contributes to the fact that consumers forget } \\
\text { about the company or its product. Require careful } \\
\text { monitoring of reputation and image. Having } \\
\text { made a few not the most effective posts, you can } \\
\text { permanently damage your reputation and lose } \\
\text { the loyalty of subscribers. The presence of high } \\
\text { competition, where everyone is trying to stand out } \\
\text { in the top leaders. }\end{array}$ \\
\hline $\begin{array}{l}\text { Targeted contextual } \\
\text { advertising }\end{array}$ & $\begin{array}{l}\text { This type of advertising is aimed at an already covered audience. } \\
\text { Advertising is immediately displayed in search engines, without } \\
\text { the mandatory optimization of the site to the requirements of } \\
\text { search engines. Provides remarketing when a potential customer } \\
\text { who has left the site for some reason is "haunted" by contextual } \\
\text { advertising on third-party resources. Ability to track spending. } \\
\text { Payment is made not for impressions by quantity or time, but } \\
\text { for the actual conversions of potential customers to the site. Fast } \\
\text { effect. Unlike the work of SEO, the work of context can be felt in } \\
\text { a shorter time. }\end{array}$ & $\begin{array}{l}\text { A small number of conversions from } \\
\text { advertisements (depending on the subject of the } \\
\text { site). Not fixed cost of the show, auction system. } \\
\text { The budget is much higher than in SEO. }\end{array}$ \\
\hline E-mail marketing & $\begin{array}{l}\text { Ability to form a target audience for various parameters: type of } \\
\text { activity, geographical location, age, etc. Detailed reporting and the } \\
\text { ability to assess effectiveness. }\end{array}$ & Obsession. Ability to get into SPAM. \\
\hline $\begin{array}{l}\text { Banner and teaser } \\
\text { advertising }\end{array}$ & $\begin{array}{l}\text { This type of advertising involves the promotion of goods } \\
\text { through the placement of banners with images and drawings } \\
\text { and text (teasers). The user clicks on the text or image goes to } \\
\text { the company's website. This provides an instant effect from } \\
\text { advertising. The main advantage is the relative cheapness } \\
\text { compared to contextual and targeted advertising. }\end{array}$ & $\begin{array}{l}\text { You need a professional approach to placing ads } \\
\text { on certain advertising platforms. } \\
\text { Relatively expensive type of advertising }\end{array}$ \\
\hline
\end{tabular}




\begin{tabular}{|c|c|c|}
\hline $\begin{array}{l}\text { Modern marketing } \\
\text { tools }\end{array}$ & Advantages & Disadvantages \\
\hline Mobile applications & $\begin{array}{l}\text { This marketing tool is used to analyze the target audience by } \\
\text { the phone models used and the traffic generated by mobile } \\
\text { applications. This makes it possible to collect data on the } \\
\text { characteristics of the target audience who use mobile applications. } \\
\text { An additional advantage is the speed of order processing, the } \\
\text { possibility of instant payments and information updates. }\end{array}$ & $\begin{array}{l}\text { The main audience of mobile application users } \\
\text { are young people aged } 20-45 \text {. High degree of } \\
\text { competition among companies operating in one } \\
\text { segment. }\end{array}$ \\
\hline Viral marketing & $\begin{array}{l}\text { Post information quickly and easily. Increase customer loyalty due } \\
\text { to the lack of irritating effect from advertising and increase trust in } \\
\text { the product. Cost-effective marketing tool. Absence of restrictions } \\
\text { and censorship }\end{array}$ & $\begin{array}{l}\text { Temporary effect. It is difficult to predict } \\
\text { the outcome of the campaign. High cost of } \\
\text { production. Target audience restrictions. }\end{array}$ \\
\hline Content marketing & $\begin{array}{l}\text { Ability to quickly gain the trust of readers. Even the first article } \\
\text { can make a company famous and bring it to the TOP in search } \\
\text { engines. Widely recognizable content. With each new publication, } \\
\text { the impression of the company, resources and product is formed, } \\
\text { customers remember the brand better. Excellent interaction with } \\
\text { SEO. Increase traffic by writing content that will work in SEO. }\end{array}$ & $\begin{array}{l}\text { We need good copywriters and authors of texts. } \\
\text { It takes time to write these texts. It is not always } \\
\text { high the conversion of content advertising } \\
\text { readers into the company's clients. }\end{array}$ \\
\hline Native advertising & $\begin{array}{l}\text { With the right approach allows you to recoup costs several times. } \\
\text { This type is not intrusive to consumers unlike teaser and banner } \\
\text { advertising. }\end{array}$ & $\begin{array}{l}\text { Requires a significant investment. Does not bring } \\
\text { fast results. }\end{array}$ \\
\hline Messengers & $\begin{array}{l}\text { An effective free tool for quick personal appeal to the target } \\
\text { audience and promotion of the company. }\end{array}$ & $\begin{array}{l}\text { Negative reaction of consumers to personal } \\
\text { advertising messages }\end{array}$ \\
\hline Storytelling & $\begin{array}{l}\text { Influences the consciousness of people, inspires them with the } \\
\text { necessary thoughts, forms involvement and is able to cause the } \\
\text { planned reaction and further behaviour. The effectiveness of } \\
\text { storytelling is due to the suppression of denial and unconscious } \\
\text { rejection of information }\end{array}$ & $\begin{array}{l}\text { Needs the use of experienced and creative } \\
\text { professionals. Forever successful and protracted } \\
\text { stories }\end{array}$ \\
\hline Gamification & $\begin{array}{l}\text { Provides adaptation of game methods to non-game processes } \\
\text { and events for greater involvement of participants in the process. } \\
\text { Has a high level of emotional involvement and promotes better } \\
\text { assimilation of information }\end{array}$ & $\begin{array}{l}\text { The main target audience is Generation Z. Not } \\
\text { suitable for most consumer goods. }\end{array}$ \\
\hline
\end{tabular}

Source: based on the results of the authors' expert assessments

responsible relations in the practical business sphere, which becomes possible through the implementation of the concept of socio-ethical marketing.

\section{Conclusion}

The research allowed us to conclude that the social responsibility of business is based on the creation of a system of social relations in terms of compliance with certain social standards and norms, the mechanism of which can be implemented through the concept of socio-ethical marketing. This approach contributes to the creation of a system of relations with consumers of goods and services, which guarantees security and progressive development, ensures the coordination of the interests of the subjects involved in these relations and their management. In the context of the introduction of such an approach, modern marketing tools are used, which meet the conditions of digitalization of the economy and society as a whole. However, its use creates certain risks and dangers of unethical dissemination of personal data.

\section{References:}

Aaker, D. (2003). Sozdanie silnyh brendov [Building strong brendov]. Moscow: Publishing House of Grebennikov, 440.

Barna, M., Melnyk, I., \& Baran, R. (2021). Factors of digitalization of the marketing activity of tourist enterprises of Ukraine in the conditions of global digitalization. Baltic Journal of Economic Studies, 7(3). DOI: https://doi.org/10.30525/2256-0742/2021-7-3-29-36

Chukurna, O. (2020). Methodical Approach to Accounting Intangible Assets and Brand Values in Marketing Pricing Policy. Marketing and digital technologies, 4(3), 63-72. Available at: http://mdt-opu.com.ua/index.php/ $\mathrm{mdt} /$ article/view/111/104

Compare the Market / Keep Life Simples. June 4, 2021. Available at: https://www.comparethemarket.com

Data Bridge. June 10, 2021. Available at: https://www.databridgemarketresearch.com/reports/global-virtualreality-markt 
Vol. 2 No. 3, 2021

Drucker, P. (2004). Encyclopedia of Management trans. 10th ed. Moscow: Williams Publishing House, 432.

Frederik, E., \& Webster, Jr. (1997). The Future Role of Marketing in the organization. Reflections on the Future of Marketing. Cambridge, 39-66.

Egan, D. (2006). Relationship Marketing. Analysis of marketing strategies based on relationships (2nd ed.). St. Petersburg: Peter, 346.

Kevin Lane, Keller (2005). Strategicheskij brend-menedzment: sozdanie, ocenka i upravlenie marochnym kapitalom [Strategic brand management: creating, assessment and management of branded capital]. Moscow: Publishing House "Williams", 509.

Kotler, F., \& Keller, K. (2012). Marketing. Management [trans. from English]. 12th edition. St. Petersburg: Piter, 816.

Lamben, J. J. (2004). Market-oriented management [Trans. with English] / ed. by. V. B. Kolchanova. St. Petersburg: Piter, 800.

Martyniuk, O. A. (2020). The impact of digital technologies on the development of business social responsibility. Economics: time realities. Scientific journal, 4(50), 78-86. Available at: https://economics.opu.ua/files/archive/ 2020/No4/78.pdf.

Nitsenko, V., Chukurna, O., Mardani, A., Streimikis, J., Gerasymchuk, N., Golubkova, I., \& Levinska, T. (2019). Pricing in the Concept of Cognitive Marketing in the Context of Globalization: Theoretical, Methodological and Applied Aspects. Montenegrin Journal of Economics, 15(4), 131-147. Available at: http://dspace.opu.ua/jspui/ bitstream/123456789/10377/1/131_-147___sin_dalii_et_al.pdf

Oklander, M. (2020). Marketing as an economic science. Marketing and digital technologies, 4, 62-70. DOI: https://doi.org/10.15276/mdt.4.4.2020.4

Porter, M. (2005). Competition: [trans. from English]. Moscow: Publishing House "Williams", 608.

Temporal, P., \& Trott, M. (2002). A novel with a buyer / Per. from English ed. Yu.N. Kanturevsky. St. Petersburg: Peter, 224. 